\title{
Chasing the Chimera: The Rule of Law in the British Empire and the Comparative Turn in Legal History
}

\author{
John McLaren
}

This article compares the imposition, application and evolution of the Rule of Law in colonial territories and their populations within the British Empire as evidence of a 'Comparative Turn' in exploring metropolitan and colonial legal cultures and their interrelationships. The purpose of the study is not primarily to either justify or criticise that concept, but to suggest that its complexity, contingency and controversy provides fertile soil for research relating to law and justice, and their ideologies across the British Empire.

\begin{abstract}
Elsewhere there might be the sultan's caprice, the lit de justice, judicial torture, the slow-grinding mills of the canon law's bureaucracy, and the auto-da-fé of the Inquisition. In England, by contrast, king and magistrates were beneath the law, which was the even-handed guardian of every Englishman's life, liberties, and property. Blindfolded Justice weighed all equitably in her scales. The courts were open, and worked by known and due process. Eupeptic fanfares such as those on the unique blessings of being a free-born Englishman under the Anglo-Saxon-derived common law were omnipresent background music. Anyone, from Lord Chancellors to rioters, could be heard piping them (though for very different purposes). ${ }^{1}$
\end{abstract}

There is inherent value and potential in comparing the legal cultures of former British colonial territories to demonstrate the processes of the translation of legal culture and ideology, not only from the metropolis to the colonies, but between the colonies themselves, and the institutional and personal networks and trajectories that facilitated these movements. Historians of imperial webs, networking and conceptual and linguistic influences are already pointing the way in this regard. ${ }^{2}$ This kind of broader contextual scholarship enriches understandings of the flow of ideas about law and regulation within an imperial system, the degree of diversity of legal ordering that existed across empire, and the sites and character of resistance to the imposition of alien conceptions of social ordering. ${ }^{3}$ There are a variety of contexts that one could use: constitutional

$1 \quad$ Roy Porter, English Society in the Eighteenth Century (Penguin, 1982) 149.

2 See Zoe Laidlaw, 'Breaking Britannia's Bounds? Law, Settlers, and Space in Britain's Imperial Historiography' (2012) 55(3) The Historical Journal 807-830 for an overview of current trends in historical scholarship of empire.

3 See, eg, Catherine Hall, Civilising Subjects: Metropole and Colony in the English Imagination (Cambridge University Press, 2002); Kerry Ward, Networks 
evolution; lawyers and the legal profession; the role of judges and the law officers; settlement and its impact on Indigenous populations and their conceptions of property; internal security of the colonial state; the treatment of women, labour, the racial 'other' and other subjects of empire; as well as various aspects of private law. ${ }^{4}$ The subject chosen here is the Rule of Law in discourse, rhetoric and action across the British Empire.

Comparing the imposition, application and evolution of external legal systems on colonial territories and their populations within the British Empire is a scholarly endeavour that is coming of age. We have moved beyond what the late Graham Parker described as the 'cultural cringe', the traditional subservience to the primacy of English legal culture and its record in the former colonies, evident in the longstanding obsession with teaching English legal history in some of those territories, and silence on local inspirations, initiatives, developments and interactions. ${ }^{5}$ In the former settler colonies, such as Australia, Canada and New Zealand, both the preservation of locally produced records and the encouragement of indigenous scholarship, ${ }^{6}$ and in the former multiracial empire, the

of Empire: Forced Migration in the Dutch East India Company (Cambridge University Press, 2009); Alan Lester, Imperial Networks: Creating Identities in Nineteenth Century South Africa and Britain (Routledge, 2001); Tony Ballantyne, Webs of Empire: Locating New Zealand's Colonial Past (Bridget Williams Books, 2012); Zoe Laidlaw, Colonial Connections 1815-45: Patronage, the Information Revolution and Colonial Government (Manchester University Press, 2005); Antoinette Burton, Empire in question: Reading, Writing, and Teaching British Imperialism (Duke University Press, 2011).

4 For helpful and suggestive studies of and collections of essays on subjects in comparative colonial legal history, see, eg, Lauren Benton, Law and Colonial Cultures: Legal regimes in World History (Cambridge University Press, 2002); Lauren Benton, A Search for Sovereignty: Law and Geography in European Empires 1400-1900 (Cambridge University Press, 2010); RW Kostal, A Jurisprudence of Power: Victorian Empire and the Rule of Law (Oxford University Press, 2005); Shaunnagh Dorsett and Ian Hunter (eds), Law and Politics in British Colonial Thought: Transpositions of Empire (Palgrave Macmillan, 2010); Shaunnagh Dorsett and John McLaren (eds), Legal Histories of the British Empire: Laws, Engagements and Legacies (Routledge, 2014); Hamar Foster, Benjamin L Berger and AR Buck (eds), The Grand Experiment: Law and Legal Culture in British Settler Societies (University of British Columbia Press, 2008); Robert A Huttenback, Racism and Empire: White Settler and Coloured Immigrants in the British Self-Governing Colonies, 1830-1910 (Cornell University Press, 1976); Peter Karsten, Between Law and Custom: "High" and "Low" Legal Cultures in the Lands of the British Diaspora - The United States, Canada, Australia and New Zealand, 1600-1900 (Cambridge University Press, 2002); Diane Kirkland and Catherine Coleborne (eds). Law, History, Colonialism: The Reach of Empire (Manchester Press, 2001); John Weaver, The Great Land Rush and the Making of the Modern World (McGill-Queen's Press, 2003); Lisa Ford, Settler Sovereignty: Jurisdiction and Indigenous People in America and Australia 1788-1836 (Harvard University Press, 2010).

5 Graham Parker, 'Canadian Legal Culture' in Louis A Knafla (ed), Law and Justice in a New Land: Essays in Western Canadian Legal History (Carswell, 1986) 3, 18-20.

6 The Australian collections of case and litigation records (especially those for New South Wales and Tasmania) and the Lost Cases collection for New Zealand 
ongoing investigation of the interaction of imported legal systems and local legal, political and social cultures is producing a critical mass of research and scholarship that invites comparisons and contrast between and across jurisdictions. ${ }^{7} \mathrm{We}$ are, I believe, engaged in the 'Comparative Turn' in exploring metropolitan and colonial legal cultures and their interrelationships.

Anyone seeking to delve into the history of the Rule of Law in the Anglo-American world might well be accounted a fool. It is so freighted with diverse political, social, and even economic baggage that it is easy to become lost in a maze of contingent claims and interpretation. ${ }^{8}$ Even as a mantra of justice it is by any standards an imprecise and contested notion. Its invocation by Barack Obama on the one hand and Robert Mugabe on the other, might well suggest it has lost any pretence of meaning, and should be cast into the ash can of noble, but useless, ideas, as some scholars have argued. ${ }^{9}$

It is also controversial. Although Whiggish enthusiasts have seen it as a significant British contribution to human progress, ${ }^{10}$ several scholars on the left have attacked it, arguing that it amounts to an elite ruse to dignify inherently unjust and oppressive legal systems. ${ }^{11}$ However, despite attempts at erasure or intellectual burial, the Rule of Law is

can be accessed through AustLII: <http://www.austlii.edu.au/au/special/legalhistory/>. For the Osgoode Society for Canadian Legal History that has encouraged an outpouring of scholarship on Canadian legal history, see: <http://www. osgoodesociety.ca/Books/Publishing_Programme.html>. For other imaginative and revealing studies of records in monograph form, see, eg, Heather Douglas and Mark Finnane, Indigenous Crime and Settler Law: White Sovereignty and Empire (Palgrave MacMillan, 2012).

7 See, eg, Dorsett and McLaren, Legal Histories, above n 4; Elizabeth Kolsky, Colonial Justice in British India: White Violence and the Rule of Law (Cambridge University Press, 2010); Martin Wiener, An Empire on Trial: Race, Murder and Justice under British Rule (Cambridge University Press, 2009); Anindita Ghosh (ed), Behind the Veil: Resistance, Women and the Everyday in Colonial South Asia (Palgrave Macmillan, 2008).

8 Brian Z Tamanaha, On the Rule of Law: History, Politics, Theory (Cambridge University Press, 2004) 9, quoting from Aristotle, Politics, III, 1286, 78.

9 In his inaugural address, President Obama reaffirmed that his administration would uphold and be guided by the Rule of Law: <http://www.cbsnews.com/ stories/2009/01/20/national/inauguration09/main4737816.shtml?tag=mn>._For the Mugabe quote, see Tamanaha, On the Rule of Law, above n 8, 2. For an example of the dismissive strain of opinion, see Judith N Shklar, 'Political Theory and the Rule of Law' in Allan C Hutchison and Patrick Monahan (eds), The Rule of Law: Ideal or Ideology (Carswell, 1987) 1. Professor Shklar quickly adds that as a historian she cannot disregard the Rule of Law as an ideological construction.

10 See, eg, Niall Ferguson, Empire: How Britain Made the Modern World (Basic Books, 2003) xxii.

11 For a horrified reaction to EP Thompson's treatment of the Rule of Law and his reference to it as 'an unqualified good' in Whigs and Hunters: The Origin of the Black Act (Pantheon Books, 1975) 258-269, at 267, see Morton Horwitz, 'The Rule of Law: An Unqualified Human Good' (1977) 86 Yale Law Journal 561. For a post-colonial critique, see Ranajarit Guha, Dominance without Hegemony: History and Power in Colonial India (Harvard University Press, 1997). 
so embedded in the Western legal consciousness and attractive at a rhetorical and discursive level that it has survived, and even prospered. Complex and contested though it is, it continues to hover over the conduct of human and, indeed international relations, as an aspirational ideal, a gauge for legal, political and moral judgment, and, on occasion, a stimulus to action. ${ }^{12}$

Roy Porter, in the elegant and apt opening quotation above, used a musical metaphor to point to the Rule of Law's pervasiveness in 18th century English discourse. I employ that of a mythical creature constructed out of various animal species. My purpose is not primarily to either justify or criticise the concept. It is rather to suggest that its contingency and the controversy surrounding it provides fertile soil for research into law and justice and their ideologies and cultures in the British Empire. I point to several insights from my own research on judicial tenure and the bad boys of the colonial judiciary, and other fields of speculation that seem to me to be ripe for further exploration.

Despite the narrower juristic version later associated with Alfred Venn Dicey, ${ }^{13}$ the Rule of Law in late 18 th century Britain was a tensile notion. Conservatives and liberals might agree on some of its claims: the right to justice by the judgment of one's peers and the law of the land; ${ }^{14}$ trial by jury; ${ }^{15}$ habeas corpus; ${ }^{16}$ freedom from royal suspension of or dispensation from laws of Parliament; ${ }^{17}$ the independence of the judiciary; ${ }^{18}$ and freedom from arrest under general warrants. ${ }^{19}$ Allied with the Rule of Law were a series of 'constitutional rights', some of which seemed settled, such as no taxation without representation and the right to petition the Crown, and others that were contentious between conservatives and liberals or radicals - freedom of the press, freedom of association, freedom of

12 See Ian Duncanson, Historiography, Empire and the Rule of Law: Imagined Constitutions, Remembered Legalities (Routledge, 2013).

13 AV Dicey, Introduction to the Study of the Law of the Constitution (St. Martin's Press, 1961) 183-203.

14 Magna Carta (1215), articles 39 and 40. On the Ancient Constitution and its impact on English and British legal thought, see Ellis Sandoz (ed), The Roots of Liberty: Magna Carta, Ancient Constitution, and the Anglo-American Tradition of Rule of Law (University of Missouri Press, 1993), and for insights into the most recent scholarship on the Great Charter, see Claire Breay and Julian Harrison, Magna Carta: Law, Liberty and Legacy (British Library, 2015).

15 In Bushell's Case (1670) 6 State Trials 1006 (KB), Chief Justice Vaughan denied a power in the judiciary to imprison jurors for verdicts which they considered perverse and against the evidence.

16 Habeas Corpus Amendment Act (1679) 31 Car II, c 2.

17 The Bill of Rights (1689) 1 Will \& Mary Sess 2, c 2.

18 Act of Settlement (1701) 12 \& 13 Will III, c 2, s 3. The independence of the judiciary in the colonies was only recognised in the mid-19th century, and then only in the white settler Empire.

19 See Leach v Money (1765) 19 State Trials 981 (KB); Entick v Carrington (1765) 19 State Trials 1045; and comment by EN Williams, The Eighteenth Century Constitution: Documents and Commentary (Cambridge University Press, 1960) 385-386, 398-399. 
assembly, freedom of conscience, and freedom of religion. In the absence of a written constitution or much resembling democracy, the Rule was seen as providing a set of standards, by which to judge the performance of those governing. Conservatives would stress formal legality, ordered liberty and deference to authority, while radicals and liberal reformers would emphasise a broader constitutional notion of liberty, and an inherent right to oppose arbitrary and corrupt governance. ${ }^{20}$ As British politics during the French Wars and their aftermath demonstrated, even settled elements of the Rule were subject to abrogation or limitation by Act of Parliament in periods of perceived emergency. ${ }^{21}$

Debates over the meaning of the Rule of Law not only in Britain, but also in the Thirteen Colonies, ${ }^{22}$ Ireland $^{23}$ and Caribbean possessions ${ }^{24}$ during the second half of the 18 th century were translated to the second empire. They were part of the cultural baggage that colonisers and colonists brought with them, and sought to imprint on their new and seemingly empty or alien surroundings. ${ }^{25}$ Given the constitutional relationships between Britain and its various colonies and British characterisation of these as 'dependencies', and especially London's use of prerogative rule or limitations on representative government, the scope of the received Rule was narrower than in Britain. Nowhere was judicial independence recognised, until introduced in the Cape Colony in $1827 .{ }^{26}$ Judges were appointed 'at pleasure' and thus subject to executive removal, a sign that they were expected both to be loyal to the colonial State, and to participate openly in and support executive government. Trial by jury was only selectively practised, as was no representation without taxation. ${ }^{27}$ Colonised populations, most notably slaves, were

20 HT Dickinson, Liberty and Property: Political Ideology in Eighteenth-Century Britain (Methuen, 1977) 121-192.

21 Boyd Hilton, A Mad, Bad \& Dangerous People: England 1783-1846 (Oxford University Press, 2006) 65-74.

22 Janice Potter, The Liberty We Seek: Loyalist Ideology in Colonial New York and Massachusetts (Harvard University Press, 1983).

23 Alan J Ward, The Irish Constitutional Tradition: Responsible Government and Modern Ireland (Catholic University of America Press, 1994) 18-20.

24 Andrew Jackson O'Shaughnessy, An Empire Divided: The American Revolution and the British Caribbean (University of Pennsylvania Press, 2000) 117-119.

25 See David Neal, The Rule of Law in a Penal Colony: Law and Power in Early New South Wales (Cambridge University Press, 1991) 61-84; Greg Marquis, 'In Defence of Liberty: 17th Century England and 19th Century Maritimes Political Culture' (1993) 42 University of New Brunswick Law Journal 69.

26 John McLaren, Dewigged, Bothered and Bewildered: British Colonial Judges on Trial 1800-1900 (University of Toronto Press, 2011) 25-42.

27 On the struggle for jury trial in New South Wales, see Bruce Kercher, An Unruly Child: A History of Law in Australia (Allen \& Unwin, 1995) 67, 72-73. A major point of conflict leading to the short-lived uprising of miners in Eureka, Victoria, in 1854 was taxation without representation, see John Molony, Eureka (Penguin, 1989); Ian MacFarlane (ed), Eureka from the Officials Records (Public Records Office of Victoria, 1995); Justin Corfield, Dorothy Wickham and Clare Gervasoni, The Eureka Encyclopaedia (Ballarat Heritage Services, 2004). 
denied even the basic protections of the dominant legal system. ${ }^{28}$ For pragmatic reasons - cost saving and strategic considerations - the British did recognise a degree of polyjurality in the 18 th century Empire. ${ }^{29}$ Both inherited European and traditional populations, for example in Quebec and India, were entitled to maintain their own laws and customs over certain aspects of their lives. In India this concession was facilitated in some regions by the recognition of 'direct rule' by local potentates, as long as they hewed to pro-British policies. Imperial policy during the 18th century tended towards recognition of Aboriginal sovereignty, customary title to land, autonomy in conducting their own governance and law, and negotiation through treaties and diplomacy. ${ }^{30}$ However, pressures of settlement, as on the Atlantic seaboard of the Thirteen Colonies, had already and continued to undercut imperial policy and the legal protections that went with it. ${ }^{31}$

The Rule of Law was part of the argot of colonial discourse on governance and the administration of justice. In a world of executive, autocratic or constrained representative government and the repressive political climate of the French Wars and their socially and economically disrupted aftermath, it provided an attractive outlet for critical comment. Even convicts were at it. John Grant, gentleman convict, in pique at being denied repatriation on the grant of a conditional pardon, inveighed against Governor King of New South Wales in 1805 in these terms: 'Now Sir! I ask you as an Independent Englishman, witnessing with astonishment the miserable state to which Thousands of Unfortunate Men are reduced in this Country, by what Authority do those in power at home, by what Right do you make Slaves of Britons in this distant quarter of the Globe? ${ }^{32}$

28 Hilary McD Beckles, "The "Hub of Empire": The Caribbean and Britain in the Seventeenth Century' in Nicholas Canny (ed), The Oxford History of the British Empire: The Origins of Empire: British Overseas Enterprise to the Close of the Seventeenth Century (Oxford University Press, 2001) vol 1, 218, 231-233; Hilary McD Beckles, A History of Barbados: From Amerindian Settlement to Nation State (Cambridge University Press, 1989) 33-35.

29 Helen Taft Manning, British Colonial Government After the American Revolution 1782-1820 (Archon Books, 1966) 293-296; see Benton, above n 4.

30 See Paul McHugh, Aboriginal Societies and the Common Law: A History of Sovereignty, Status and Self-Determination (Oxford University Press, 2004) 91-116; Peter Mancall, 'Native Americans and Europeans in English America' in Nicholas Canny (ed), The Origins of Empire: British Overseas Enterprise to the Close of the Seventeenth Century (Oxford University Press, 2001) vol 1, 328-350; Daniel Richter, 'Native Peoples of North America and the Eighteenth Century British Empire' in PJ Marshall (ed), The Oxford History of the British Empire: The Eighteenth Century (Oxford University Press, 1998) vol 2, 347-371.

31 John Weaver, The Great Land Rush and the Making of the Modern World 16591900 (McGill-Queen's University Press, 2003) 152-160; Ford, above n 4; Mancall, above n 30, 343-349; Richter, above n 30, 350-356.

32 Yvonne Cramer, This Beauteous, Wicked Place: Letters and Journals of John Grant, Gentleman Convict (National Library of Australia, 2000) 6-12 and letters to Governor King that John Grant recorded in his journal (MS 737, item 42, pp 28-29, 1-2 May 1805) 104-106 (emphasis added). 
In the settler colonies of British North America, several reformist judges, appealing to William Blackstone's emphasis on the central value of liberty of the person, property and security underlying English law for inspiration, preached a liberal version of the Rule of Law, rooted in 17th century English struggles against absolutism and the opposition of Country Whigs in the 18th. ${ }^{33}$ Between 1805 and 1807, Irishman Robert Thorpe did so to grand and petit juries in Upper Canada, in his injudicious comments to the Colonial Office, vilifying various Officers of State for abuses of power; and in his forthright statements as an elected member of the House of Assembly. ${ }^{34}$ Furthermore, he advocated a form of responsible government for the Province. ${ }^{35}$ A later successor, John Walpole Willis, during the late 1820s took the colonial administration to task for its egregiously biased administration of justice, particularly in launching criminal prosecutions against its political enemies while failing to press them against its vigilante friends, and, as he saw it, for allowing the Court of King's Bench to sit in violation of its founding statute. ${ }^{36}$

Given the insecurities of the Tory governments - a 'fortress mentality', if you will, in London, Sydney and York (Toronto) - there was a price to pay for these 'constitutionalist' criticisms. Grant was tried for his presumption and sentenced to five years on Norfolk Island. ${ }^{37}$ Thorpe and Willis were both removed from office, probably under the authority of Burke's Act of $1782 .{ }^{38}$ By contrast, jurists who hewed to a limited and contingent interpretation of the Rule, and were committed to seeking to instil order and deference among their colonial charges, survived attempts at discipline from reformist forces in colonial assemblies. Thus in Lower Canada (Quebec) Chief Justice Jonathan Sewell, confidante of governors, at times occupying the role of chief minister, successfully countered the Assembly's stratagem to have him impeached in 1815, in part for his involvement in executive repression of patriot opposition during 'Craig's Reign of Terror'. ${ }^{39}$ At that point in time there was no doubt where the

33 William Blackstone, Commentaries on the Laws of England (Clarendon Press, 1765) vol 1, 49-52, 63-73, 123-126, 130-131, 134-136.

34 McLaren, above n 26, 63-69; John McLaren, 'The King, the People, the Law ... and the Constitution: Justice Robert Thorpe and the Roots of Irish Whig Ideology in Early Upper Canada' in Jonathan Swainger and Constance Backhouse (eds), People and Place: Historical Influences on Legal Culture (University of British Columbia Press, 2006) 11-24.

35 KD McRae, 'An Upper Canadian Letter of 1829 on Responsible Government' (1950) 31(3) Canadian Historical Review 288, 291-296.

36 McLaren, above n 26, 74-83; Robert Hett, 'Judge Willis and the Court of King's Bench in Upper Canada' (1973) Ontario Historical Society 19.

37 Cramer, above n 32, 10-11 (emphasis in original). King had him tried before Judge Advocate Richard Atkins on a charge of sedition. After expressing similar sentiments to the judge, Grant was convicted and sentenced to five years' secondary transportation with hard labour on Norfolk Island.

38 McLaren, above n 26, 68-69, 82-83.

39 McLaren, above n 26, 92-98; Jean-Marie Fecteau, F Murray Greenwood and JeanPierre Wallot, 'Sir James Craig's "Reign of Terror" and Its Impact on Emergency Powers in Lower Canada 1818-1813' in F Murray Greenwood and Barry Wright 
imperial government would come down in a conflict between those committed (even in extreme ways) to furthering 'peace, order and good government', and reformers who were viewed as subverting the existing order and encouraging dissension and 'faction' among colonists.

The shadow over liberal interpretations of the Rule of Law was not to last. In Upper Canada during the 1820s, despite attempts by local Tory colonial politicians and administrators (including judges and law officers) to consolidate their power and influence, appeals to 'constitutionalist' renderings of the Rule were beginning to attract attention in London where the longstanding Tory political dynasty was weakening. A reform party in the Upper Canadian House of Assembly led by William Warren Baldwin, one of several able lawyer members, invoked the Rule of Law to press for repeal of repressive legislation, to challenge the manipulation of the justice system by the local administration, and to advocate judicial independence. ${ }^{40}$ In 1821 in that chamber, Baldwin remarked that with the draconian Sedition Act in place Upper Canadians were 'without a constitution, at least a free one'. The statute, he added, 'remained in force in the face of Magna Carta, but directly in the face of all the statutes made for the liberty and protection of the subject'. ${ }^{41}$ Although the reformers' agenda for responsible government fell on deaf ears in Westminster, their appeal for the detachment of judges from service on the Executive Council was heeded by the late 1820 s. This was the harbinger of later more dramatic moves to formal judicial independence in the North American colonies. ${ }^{42}$

A similar wellspring of liberal constitutionalism was meanwhile being appealed to in the very different colony of New South Wales. From the 1810 s there had developed tension between a professional judiciary committed to doing justice according to the precepts and rules of English law, and Governors ruling directly as autocratic agents of the imperial authorities in this hybrid convict/free settler possession. Initial skirmishes in the 1810s between two conservatives, the stiff-necked, ascetic and vainglorious judge, Jeffery Hart Bent, and the imperious, pragmatic and even creative Governor Lachlan Macquarie, resulted in

(eds), Canadian State Trials: Law, Politics, and Security Measures, 1608-1837 (University of Toronto Press, 1996) vol 1, 323-378.

40 John McLaren, 'The Rule of Law and Irish Whig Constitutionalism in Upper Canada: William Warren Baldwin, the "Irish Opposition", and the Volunteer Connection' in Jim Phillips, R Roy McMurtry and John T Saywell (eds), Essays in the History of Canadian Law: A Tribute to Peter Oliver (University of Toronto Press, 2008) 320-352.

41 Ibid, 334-335. Sedition Act, UC 1804, c 1, directed against both Bonapartist designs and the activities of United Irishmen, provided wide extra-judicial powers for the issue of warrants against non-residents and those failing to take an oath of allegiance to the monarchy who were suspected of having spread or being about to spread sedition. Procedure was summary with a reverse onus, and penalties included banishment, and death for failing to leave the colony.

McLaren, above n 26, 83-84; Paul Romney, Mr. Attorney: The Attorney General for Ontario in Court, Cabinet, and the Legislature 1791-1899 (University of Toronto Press, 1986) 151. 
the Colonial Office's recall of the former. ${ }^{43}$ Conflict continued in earnest during the 1820s between the liberal imperialist, Chief Justice Francis Forbes, and his nemesis, the authoritarian, action oriented and impatient, Governor Ralph Darling. ${ }^{44}$ Together with his colleagues in the Supreme Court Forbes sought to educate the Governor in the perils of abusing his powers, and to lay the groundwork for the Australian law of judicial review of administrative action. Moreover, in a stand that was bold, even in the context of contemporary English law, Forbes made it clear in the Newspaper Opinion of 1827 that it was an abuse of gubernatorial authority for Darling to suppress his press critics by resort to a licensing regime for newspapers and prohibitive stamp duties. ${ }^{45}$ It was, he said, repugnant to English law that treated freedom of the press as a 'constitutional value'. ${ }^{46}$ Even the Colonial Office, seemingly fed up at this point with hyperactive and contrary judges, ended up agreeing with Forbes. ${ }^{47}$

During the first third of the 19th century, the West Indies was a region of British colonial rule in which the proponents of ostensibly similar rhetorical renderings of the Rule came into conflict. On the one hand were the minority European elites trumpeting loudly the 'rights of free born Englishmen' as the bedrock of their liberties, and on the other British colonial judges sympathetic to the notion that under English understandings of the Rule of Law such exclusive renderings were offensive - an inversion of the Rule in effect. ${ }^{48}$ The campaign in Britain for the abolition of the slave trade and later of slavery generally gave heart to judges sympathetic to that cause. But it could be a perilous stand in jurisdictions in which slavery was the raison d'etre of the white presence, its economic and social interests and its system of governance and law. George Smith, the first professional Chief Justice of Trinidad (from 1808 to 1811), learnt this to his cost. His resistance to representative government on the island because, he said, it would further embed slavery, and his advocacy of the retention of Spanish law on the island, in part because fairer to both those in bondage and to free and freed Africans, rendered him both persona non grata and jobless. ${ }^{49}$

43 McLaren, above n 26, 130-140; Charles Herbert Currey, The Brothers Bent: Judge Advocate Ellis Bent and Judge Jeffrey Hart Bent (Sydney University Press, 1968) 99-150. Bent had closed his court for a year and a half in the absence of any lawyers without the convict taint in the colony, bringing civil justice in disputes of higher value to a halt. He refused to allow audience to lawyers who were former convicts, despite the urgings of the governor to continue what had been accepted past practice.

44 McLaren, above n 26, 149-155; John Michael Bennett, Sir Francis Forbes: First Chief Justice of New South Wales 1824-1837 (Federation Press, 2001) 73-82.

45 Bennett, above n 44, 83-100.

46 Newspaper Acts Opinion [1827] NSWSC 23. Press freedom in Britain was still limited by emergency legislation passed during the period of social unrest after the end of the Napoleonic Wars.

47 At about the same time the Office was dealing with ructions caused by John Walpole Willis in Upper Canada and Jeffrey Hart Bent in Grenada.

48 McLaren, above n 26, 217-219; Beckles, A History of Barbados, above n 28, 33-35.

49 McLaren, above n 26, 220-227; James Millette, Society and Politics in Colonial Trinidad, (Zed Books, 1985) 230-266; Bridget Brereton, A History of Modern Trinidad 1783-1962 (Heinemann, 1981) 32-51. 
More successful in opposing the plantocracy was Jeffrey Hart Bent. Reincarnate as Chief Justice of Grenada, in 1828-1829 he took the part of a radical Roman Catholic priest, Anthony O'Hannan, the latter's Bishop, with the connivance of the secular authorities in the colony, wanted the incumbent removed from his parish. ${ }^{50}$ This early 'liberation theologian' was highly popular with his slave and free-coloured congregants. Outflanking the local law officer and magistrates and issuing a writ of habeas corpus when the priest was arrested for refusing to give up his charge, Bent was suspended by Acting Governor Houstoun for subversive behaviour and encouraging unrest amongst the non-Europeans. During this contretemps the judge was to lecture his antagonist that he was bound by his oath of office to do his 'duty without fear, favour or affection' and would not 'swerve from the impartial exercise of the judicial functions' even under threat of discipline - a ringing invocation of judicial independence in its English form. ${ }^{51}$ Both the Colonial Office and the Privy Council implicitly upheld this view when, after a second suspension, Bent appealed to London. ${ }^{52}$

The move towards a more liberal constitutionalism in Britain's relations with its settler colonies was evident in the successful invocation of the Rule by reformist legislators against an ultra-Tory colonial judge, Henry John Boulton, in Newfoundland. ${ }^{53}$ He was removed from office on the advice of the Privy Council in 1838 on petition from the House of Assembly, for his strident political partisanship as President of the colony's Council (the upper chamber), manifest, for instance in his purposeful blocking of assembly money bills and those seeking to uphold the customs of the fishery. It was also evident in the vigorous and successful advocacy of other constitutional rights claimed, such as freedom of the Press. This was true, for example, in the case of newspaper editor Joseph Howe, acquitted by a jury of criminal libel in Nova Scotia in 1835 for exposing abuses of power and illegal exactions by the Halifax magistracy. ${ }^{54}$ Constraints on the Rule by colonial executives loosened as momentum towards responsible government built up both in British North America and then the Antipodes. With its grant, the Rule of Law and its influence became much more a matter of local politics and justice. Although liberal renderings of the Rule were influential in this process of constitutional evolution and reordering within the Empire, the meanings ascribed to it were as hotly contested in the settler colonial state with responsible government as they had been earlier in settler colonies. In some instances, indeed, conservative, anti-democratic judges argued for

50 McLaren, above n 26, 234-232; Currey, above n 43, 157-165.

51 McLaren, above n 26, 242-244.

52 Re Bent (1832) 18 Privy Council Indian and Colonial Appeals (PCICA).

53 McLaren, above n 26, 106-118; Gertrude Gunn, The Political History of Newfoundland 1832-1864 (University of Toronto Press, 1966) 19-45.

54 Barry Cahill, ' $R v$ Howe (1835) for Seditious Libel: A Tale of Twelve Magistrates' in Frank Murray Greenwood and Barry Wright, Canadian State Trials (University of Toronto Press, 1996) vol 1, 547-575. 
extended recognition of its protections in the administration of justice, especially to non-European migrants. Meanwhile, reformers, located in legislative assemblies, influenced by social Darwinism, invoked the rhetoric of opposition to slavery to limit or remove rights of such people, if not to exclude them entirely. ${ }^{55}$ With Aboriginal peoples, even judicial champions of the Rule of Law were lacking. Ironically, now classified as British subjects whether they liked that or not, they were subjected to increasingly discriminatory regimes that denied them any hope of equality within the justice system. ${ }^{56}$ The moves to more democratic forms of government in these possessions did not by any means guarantee an inclusive espousal of the Rule, where the 'Other' sought its protection whether on grounds of race, gender or class - a phenomenon that extended well into the 20th century. Moreover, even within the dominant legal culture, as Paul Halliday points out, law makers in these territories were just as prone as their British counterparts to invoking state security to justify the curtailment of Rule of Law protections such as habeas corpus..$^{57}$

Outside the white settler Empire, the story of the Rule in the late 19th century was different. In its Caribbean and Indian Ocean possessions, London, spooked by the resistance of the 'coloured peoples' to British rule, evident in the Indian Mutiny (1858) and the Morant Bay Rebellion uprising in Jamaica suppressed with ferocity under Governor Edward Eyre (1865), ${ }^{58}$ and by a strong strain of elite opinion in Britain (shared by Carlyle, Ruskin and even Dickens) pressing for firmer and repressive rule over non-European colonial populations, took a different tack. The British government determined that peace and stability could only be secured in its West Indian possessions, through rule as Crown colonies, with executives responsible directly to Westminster ${ }^{59}$ In this climate, liberal interpretations of the Rule of Law were not well-received, particularly if calculated to antagonise unduly the socio-economic power structure in

55 On the 'Asiatic other' see John PS McLaren, 'The Burdens of Empire and the Legalization of White Supremacy in Canada 1860-1910' in William M Gordon and TD Fergus (eds), Legal History in the Making: Proceedings of the Ninth British Legal History Conference Glasgow 1989 (Hambledon Press, 1991) 187-200; Raymond Evans, Kay Saunders and Kathryn Cronin, Race Relations in Colonial Queensland: A History of Exclusion, Exploitation and Extermination (University of Queensland Press, 1975) 235-240.

56 See McHugh, above n 30, 178-214; Henry Reynolds, Frontier, Aborigines, Settlers and Land (Allen \& Unwin, 1987); Henry Reynolds, The Law of the Land (Penguin Books, 1987); JR Miller, Skyscapers Hide the Heavens: A History of Indian-White relations in Canada (University of Toronto Press, 2000) 99-115; Cole Harris, Making Native Space: Colonialism, Resistance and Reserves (University of British Columbia Press, 2002).

57 Paul Halliday, Habeas Corpus: From England to Empire (Belknap Press, 2010).

58 See Kostal, above n 4; Julie Evans, Edward Eyre: Race and Colonial Government (University of Otago Press, 2005) 99-150.

59 Gad Heuman, 'The British West Indies' in William Roger Louis (ed), Oxford History of the British Empire: The 19th Century (Oxford University Press, 1998) 470, 484-485. 
the territory, as several colonial judges were to find to their cost. Joseph Beaumont, from an anti-slavery background, appointed Chief Justice of British Guiana over a local boy in 1863, ran into strong opposition both from Governor Hincks and the local plantocracy. This related to his attempts to question the past administration of criminal justice in the colony, and most especially his opposition to the use of harsh master and servant ordinances and practices against indentured labour from India and China. ${ }^{60}$ For his spirited, if increasingly injudicious, reaction to what he saw as executive abuse of the Rule of Law, the Privy Council in 1868 advised his removal from office for 'indiscretion', 'want of judicial temper', and tending to embarrass the colonial government. ${ }^{61}$ Bridget Brereton has charted the career of an even more remarkable example of these judicial 'stormy petrels', Sir John Gorrie. ${ }^{62}$ Gorrie, who served in sequences as a justice in Mauritius and then as Chief Justice of Fiji, the Leeward Islands and Trinidad and Tobago, was fearless in taking up the cause of the underdogs in these territories, be they be actual or recent indentured workers, former slaves or sharecroppers. Having survived local elite criticism because of gubernatorial protection and/or colonial office satisfaction with his 'no nonsense' approach to justice and governance, he met his Waterloo in his last posting. There his increasing garrulousness and tendency to manipulate the law to afford greater access to the dispossessed, together with the enduring hatred of his enemies, induced the governor to suspend him from office. He died on his way home to England to appeal to the Judicial Committee.

In some of the new territories acquired in Africa the British, for reasons of cost-saving, trade considerations, and the imperial government and colonial bureaucracies' attraction to traditional, hierarchical structures of governance, used the model of indirect rule, already tried and tested in India. ${ }^{63}$ Here English and customary law were allowed to exist side-by-side in an uneasy relationship. In these possessions, in addition to competing interpretations of the Rule within the British colonial community, there was the additional issue of whose Rule of Law should apply, that of English or customary law. Amidst the juristic muddles that often marked the lives of these colonies, the colonial court structure with the Judicial Committee of the Privy Council at the apex took on itself the task of determining how customary law should be divined, and in sorting out which law and its rule should apply. ${ }^{64}$

$60 \quad$ McLaren, above n 26, 248-263; Basedo Mangru, 'The Hincks-Beaumont Imbroglio: Partisan Politics in British Guiana in the 1860s' (1987) 43 Boletin de Estudios Latinoamericanos y del Caribe 99.

61 McLaren, above n 26, 261.

62 Bridget Brereton, Law, Justice and Empire: The Colonial Career of John Gorrie 1829-1892 (University Press of the West Indies, 1997).

63 See, eg, Nigeria - Kwasi Kwarteng, Ghosts of Empire: Britain's Legacy in the Modern World (Public Affairs, 2011) 273-297.

64 See, eg, Bonny Ibhawoh, Imperial Justice: Africans in Empire's Courts (Oxford University Press, 2013); Stacey Hynd, 'Benjamin Knowles v Rex: Judging Murder, 
As Martin Wiener has argued, in An Empire on Trial, the period between 1870 and 1930 in the legal history of Empire was to propel liberal and inclusive interpretations of the Rule of Law to centre stage again, as some imperial and colonial officials, including judges and lawyers, took firmer stands on the notion of equal justice under the law in British possessions, such as India and Kenya ${ }^{65}$ He notes also that 'subject peoples' and their representatives, active in arguing for greater political representation and ultimately for independence, vigorously invoked the rhetoric and discourse of more liberal renderings of the Rule. This in pointing to the serious inequalities of treatment in colonial justice systems as blots on the ideology of justice that the British preached as one of the great benefits of imperial rule. Unlike the late 19 th century, in the 20 th century jurists who took on colonial executives and the socio-political elites in the territories in which they served in the name of a liberal construction of the Rule did not, it seems, pay the price of their presumption in terms of formal removal (the Colonial Office wanted to be seen as recognising de facto judicial independence).$^{66}$ One might speculate from several episodes, however, that there were other methods deployed in separating outspoken judges from their antagonists. They were either moved on to other postings or given early retirement. ${ }^{67}$

Thus far my focus has been contested interpretations of the Rule of Law as variously understood within British and colonial legal or constitutional thinking. While I have largely focused on independence of the judiciary, there are a range of other issues involving contention over the Rule that merit scholarly interest. Recent work points the way. The demotion of trial by jury, formerly a bastion of a claims of community involvement in the justice process, through 19th century reforms in the cause of both greater efficiency and responding to disgruntlement among actual and potential jurors have been aired in the work of Blake Brown. ${ }^{68}$ Paul Halliday in the final chapter of his wide-ranging study of the history of habeas corpus implicitly challenges legal historians of Empire to take up the work of examining the writ's use and limitation in the colonies. ${ }^{69}$ Every other

Race and Respectability from colonial Ghana to the Judicial Committee of the Privy Council, 1928-30' in Dorsett and McLaren, above n 4, 77-91.

65 Wiener, above $\mathrm{n} 7,1-19,156-221$.

66 McLaren, above n 26, 296-302.

67 Ibid. Note the case of Chief Justice Michael McDonnell of Mandate Palestine (1927-1937), retired early for his pro-Arab sentiments and harsh criticism of the British administration for deception in using public health and town planning justifications for destroying the old quarter of Jaffa for military purposes: El-Qasir v Attorney General and District Commissioner of Jaffa [1936] Law Reports of Palestine 121 (SC). Interestingly, in the past 10 years there have been two cases from British possessions involving appeals against suspension by judges of those jurisdictions - see Hearing re the Chief Justice of Gibraltar [2009] UKPC 43; Hearing re Justice Levers of the Grand Court of the Cayman Islands [2010] UKPC 24.

68 R Blake Brown, A Trying Question: The Jury in Nineteenth Century Canada (University of Toronto Press, 2009).

69 Halliday, above $\mathrm{n} 57$. 
aspect of the basic elements of the Rule and the constitutional values that overlap with it are ripe for further research. The compromising of the Rule of Law in the cause of the internal security of the colonial state is one rich with possibility. Brian Simpson laid the groundwork in the early chapters of his magisterial Human Rights and the End of Empire. Rande Kostal's study of the harsh treatment of localised violence in Jamaica and the role of martial law in that episode and elsewhere in empire demonstrates how imperial anxieties could be and were translated to and internalised in metropolitan politics and law. Several historians of colonialism have produced suggestive case studies of the excessive and harsh authoritarianism, not least on the suppression of the Mau Mau movement in Kenya, that are worthy of emulation in studies of other parts of empire. ${ }^{70}$

Another area of potential research is the relationship between imperialism, the Rule of Law and democracy. Despite Whiggish claims to the contrary, as Kwasi Kwarteng asserts in Ghosts of Empire, governance in the British Empire was not meant to be democratic. "The British Empire was', in Kwarteng's words, 'not simply a forerunner of the modern pluralist democracy so valued in the West. It was something entirely different ... Notions of democracy could not have been further from the minds of imperial administrators themselves. ... "Benign authoritarianism" would be a better description of the political philosophy that sustained the empire. ${ }^{71}$ The emergence of the Rule of Law preceded the rise of democracy in Britain itself, and in the Empire existed without reference to that form of government. I have also noted that the Rule was in some circumstances given a liberal cast by thoroughly anti-democratic judges. All this suggests the need to disentangle the history of the Rule from modern presentist interpretations that link it uncritically with democracy, not to mention in some iterations, the 'free market'. Ian Duncanson's recent study, Historiography, Empire and the Rule of Law, demonstrates the value of a broader theoretical, conceptual and historiographic approach to the subject. $^{72}$

There is an important ideological dimension to all of this and that is the relationship between the Rule of Law, as understood in Anglo-American thinking, and other legal cultures in colonial societies. The positive glow of the Rule, at least in its more liberal representations, can easily fade when considered not as an ameliorating concept in a dominant justice system, but as a tool in the suppression of competing legal cultures. What Douglas Hay in his early work identified as the hubris of British administrators and judges, assuming that the French speaking population of Quebec valued the application of English criminal justice to them because

70 AWB Simpson, Human Rights and the End of Empire: Genesis of the European Convention (Oxford University Press, 2004). For British handling of the Mau Mau crisis, see, eg, David Anderson, Histories of the Hanged: The Dirty War in Kenya and the End of Empire (Weidenfeld \& Nicholson History, 2005); Caroline Elkins, Imperial Reckoning: The Untold Story of Britain's Gulag in Kenya (Henry Holt, 2005).

$71 \quad$ Kwarteng, above n 63, 8.

72 Duncanson, above n 12. 
inherently more just than its predecessor, has broader implications. ${ }^{73}$ It is at the centre of a body of critical scholarship that argues that the Rule of Law was part of an inherently oppressive and dominating system that was of no value, and indeed deeply threatening, to the Aboriginal or traditional occupants and cultures of colonised territories. Robert Williams Jr has argued that in the case of North America for example, Western conceptions of law, most notably the Rule of Law, were deployed in a conscious process of erasure of the law and custom of peoples who simply wished to be left to their own ways and devices. ${ }^{74}$ Where Aboriginal peoples resorted as they did, to couch their claims in the conceptual language of the dominant legal system, their motivations were strategic rather than representing any strong intellectual or emotional commitment to the Rule of Law in the British sense. ${ }^{75}$ Ranjarit Guha has made a similar point about British India. Although elite interests among the indigenous peoples might buy into elements of the imposed Rule of Law, the vast bulk of the population were the objects of coercion by the imperial political and legal culture which had no relevance or value to them. ${ }^{76}$ Imperial governance was characterised by dominance rather than hegemony - coercion rather than persuasion, and met with resistance rather than collaboration by the subject peoples. ${ }^{77}$ Other scholars, including Lauren Benton and Sally Merry Engle have taken a more nuanced approach and laid emphasis on negotiation, albeit imperfect, across cultural boundaries in the colonial experience, and the utility of the Rule of Law in the British sense as a repository of ideas among the colonised about liberty, the fair and equal administration of justice, and important constitutional rights. ${ }^{78}$ My point here is not to suggest preferences of one interpretation over another, but to point to the rich nature of these ideological and theoretical debates, and the need to relate them to painstaking historical research in a variety of contexts in which the Rule is an issue. Here the comparative turn provides a rich terrain of evidence, the exposure of which will likely point to an

73 Douglas Hay, 'The Meanings of Criminal Law in Quebec 1764-1774' in Louis Knafla (ed), Crime and Criminal Justice in Europe and Canada (Wilfred Laurier University Press, 1981) 77.

74 Robert Williams Jr, The American Indian in Western Legal Thought: The Discourses of Conquest (Oxford University Press, 1990).

75 Hamar Foster and Benjamin Berger, 'From Humble Prayers to Legal Demands: The Cowichan Petition of 1909 and the British Columbia Land Question' in Foster, Berger and Buck, above n 4, 240.

76 Ranajarit Guha, Dominance without Hegemony: History and Power in Colonial India (Harvard University Press, 1997) ix-xiv.

77 Ibid, 20-23.

78 Benton, above n 4, 253-265; Sally Engel Merry, 'Review: Law and Colonialism' (1991) 25(4) Law and Society Review 889. For informative and balanced discussions of the interface between law and colonialism based on the historical records, see Douglas C Harris, Fish, Law and Colonialism: The Legal Capture of Salmon in British Columbia (University of Toronto Press, 2001) 186-216; Douglas C Harris, Landing Native Fisheries: Indian Reserves and Fishing Rights in British Columbia (University of British Columbia Press, 2008). 


\section{LEGAL HISTORY TURNS}

even more complex but fascinating set of historiographic strands and ideological explication than we currently possess.

I end, as I began, with a quotation, this time by Hamar Foster and Ben Berger, in the context of Aboriginal claims to title over land in my home province of British Columbia that sums up well the complex reality of the Rule of Law as a field of scholarly endeavour and points to both its importance and challenges:

[T] he ubiquity of the concept has not only made the definition of the rule of law elusive; its uniform rhetorical acceptance has often veiled the concrete realities of living under it. The rhetoric occludes the meaning of living within the culture of law's rule, including the dynamics of local power, economics, exclusion, resistance, and transformation that exist beneath the surface of even the most pristine and venerable traditions of the rule of law. The rule of law thus matters deeply but hides much. ${ }^{79}$ 